\title{
IMPROVEMENT OF THERMAL OXIDATIVE CHARACTERISTICS OF DIESEL FUELS WITH ESTERS OF CYCLIC POLYATOMIC ALCOHOLS
}

\author{
L.M.Yusifova \\ Y.Mammadaliev Institute of Petrochemical Processes, NAS of Azerbaijan \\ yusifova.lale1989@gmail.com
}

Received 27.01.2020

Accepted 07.04.2020

\begin{abstract}
A number of symmetric, asymmetric and complex esters of 2,2,5,5-tetramethylolcyclopentanol and 2,2,6,6-tetramethylolcyclohexanol were synthesized, their physicochemical, viscosity-temperature and thermo-oxidative properties were studied. With the addition of these esters to hydrotreated diesel fuels $0.004 \%$ it was possible to significantly improve the operational properties of fuels: to increase thermal oxidative stability, flash point and lower pour point. Proceeding from these results, the esters of cyclic polyatomic alcohols are recommended as complex additives to diesel fuels.
\end{abstract}

Keywords: esters of cyclic polyols, lubricating oils, diesel fuel, operational characteristics, complex additives.

doi

\section{Introduction}

To improve environmental characteristics the removal of sulfur- and nitrogen-containing heterocyclic compounds from diesel fuels (DF) is required, which leads to a decrease in oxidative stability, since sulfur and nitrogen compounds are natural antioxidants and contribute to the inhibition of the oxidation of DF. Following from this, the most effective and cost-effective way to protect DF from oxidative degradation is the use of various antioxidant additives.

Currently, extensive research is underway on the thermo-oxidative transformations of DF and the search for new effective antioxidants. It is required to select such compounds which stabilize a DF, at the same time without interacting with its components responsible for the main operational indicators.

At present, to increase thermal oxidative stability (TOS), antioxidant additives are used (added to the fuel in an amount (0.04-0.05)\%), which are a composition of 2,6-di-tert-butyl-4methylphenol (ionol), nitrogen- or a sulfurcontaining derivative of shielded phenol, up to 100 mass\% by weight of an organic solvent [1]; the composition of 2,2-methyl-bis (4-methyl-6tert-butylphenol), an oil solution of alkenyl succinimide, bis-(3.5-di-tert-butyl-2-hydroxybenzylidine) ethylenediamine etc. [2, 3]. However the- se additives and their compositions at their application the operational properties of fuels is improve insufficiently. For instance, using ionol in an amount of $0.04 \%$, the precipitate is 1 $\mathrm{mg} / 100 \mathrm{ml}$ of fuel. This figure currently does not meet the requirements of Euro-4 and Euro-5.

Therefore, the creation of new effective fuel additives is a very relevant scientific, practical and environmental problem. From this point of view, the synthesis of new esters of cyclic polyatomic alcohols of various structures and their study as additives to diesel fuels has is of certain scientific and practical significance.

Since the synthesized esters have symmetric, asymmetric, complex structures, five and six membered cyclic fragments, most polar ester groups should has is of a positive effect on the properties of fuels [4-6].

\section{Experimental part}

The starting cyclic polyatomic alcohols 2,2,5,5-tetramethylolcyclopentanol (TMCP) and 2,2,6,6-tetramethylolcyclohexanol (TMCH) were synthesized by the aldol condensation of cyclopentanone and cyclohexanone with formaldehyde according to the CannitzaroTishchenko reaction according to the following scheme: 


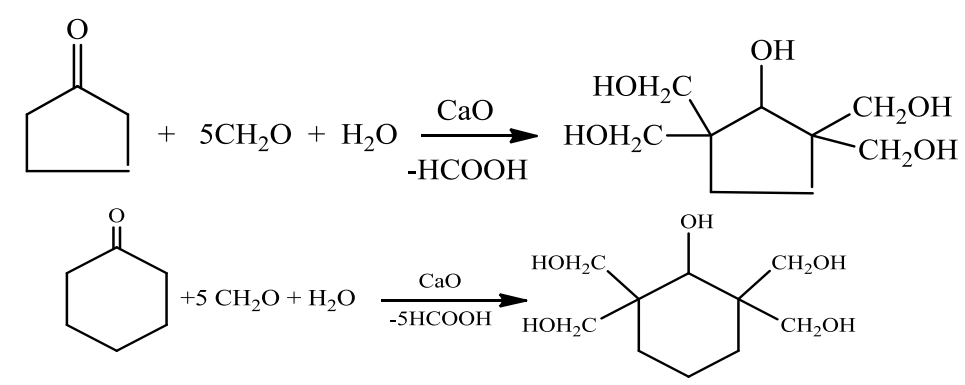

Symmetric esters were obtained by esterification of TMCP and TMCH with caproic acid, taken in a molar ratio of alcohol:acid of 1:5.5 in the presence of a catalyst of para-toluenesul-

fonic acid (PTSA) taken in an amount of $1 \%$ of the mass of the reaction mixture, until the release of reaction water is stopped [4,5].

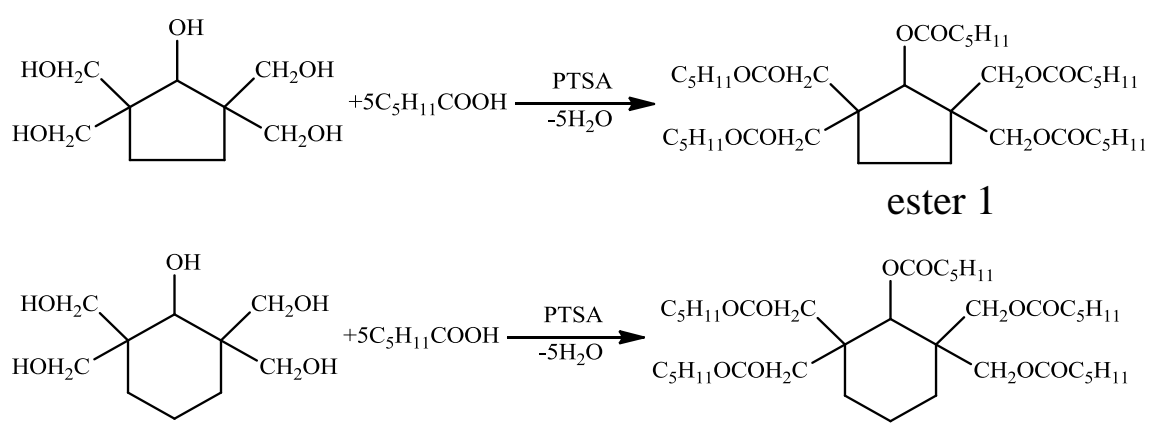

ester 2

Asymmetric esters were obtained in 2 were obtained, then in the second stage free stages: in the first, diesters with enanthic acid hydroxyl groups were esterified with caproic acid:<smiles>CCOCC1(CO)CCC(CO)(COCCCCCCC2(CO)CCC(CO)(CO)C2O)C1O</smiles>

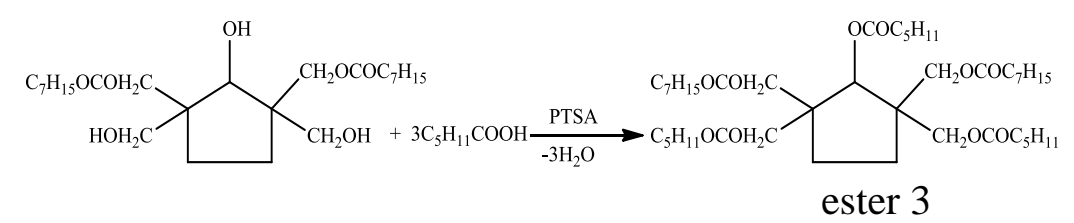

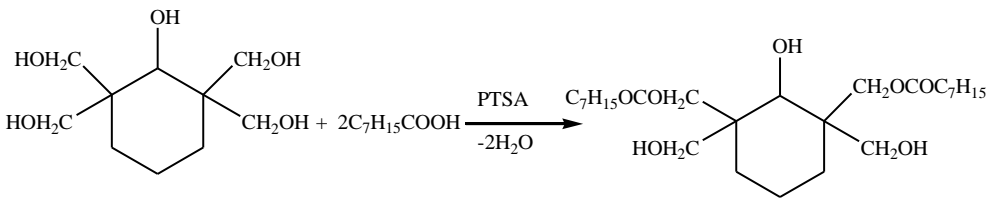

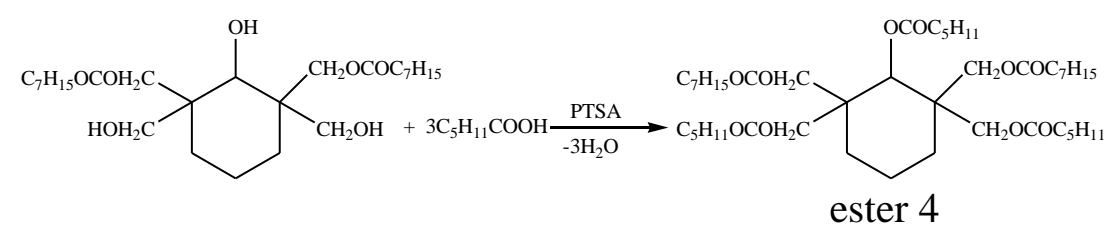

The complex esters of TMCP and TMCH were obtained in three stages: at the first stage, tetraesters were obtained by esterification of alcohols with caproic acid, at the second stage, the free hydroxyl group was esterified with pimelic acid, and at the third stage, the free carboxyl group of the acid was esterified with hexyl alcohol: 

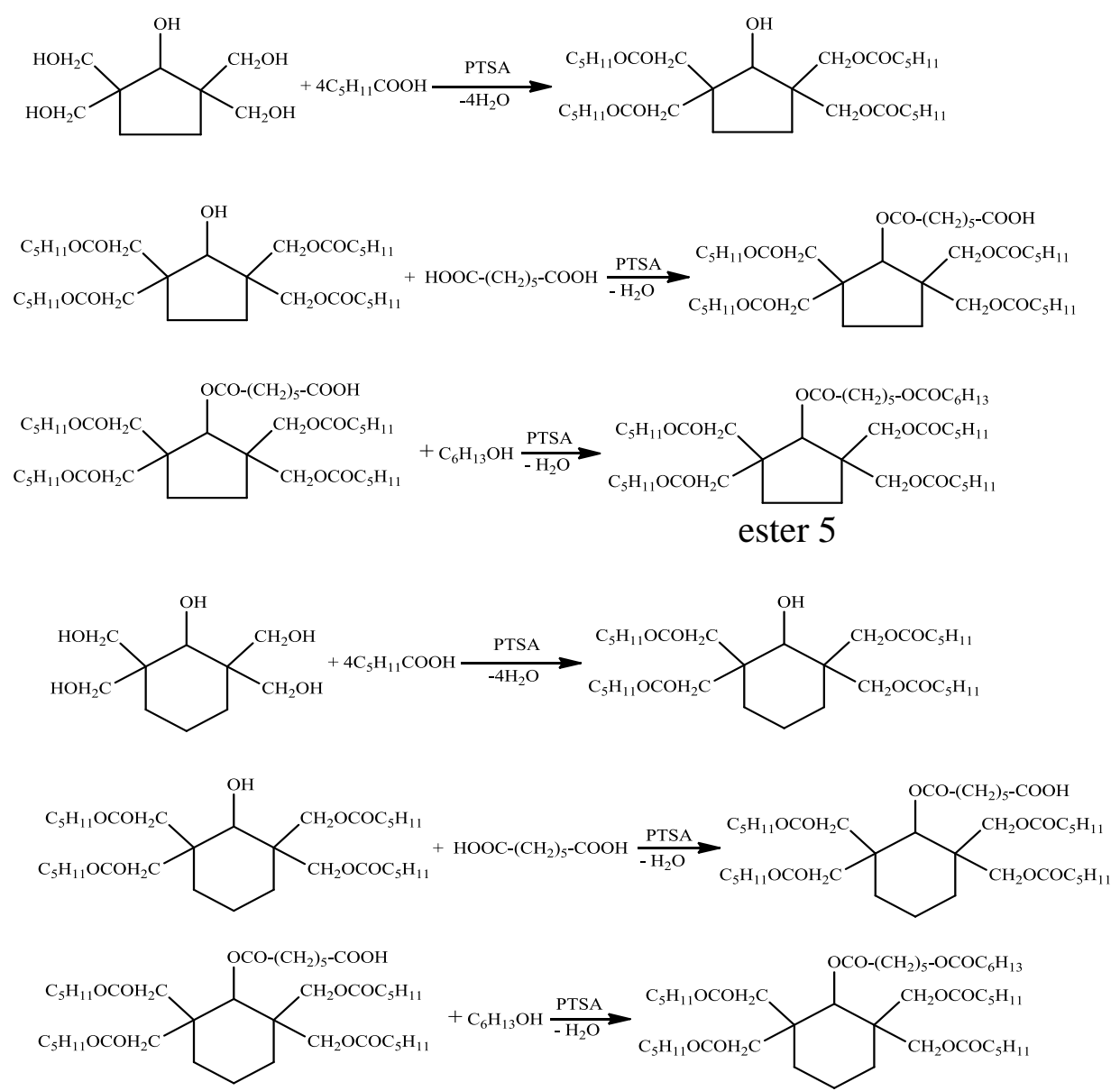

ester 6

The structure of the synthesized esters is proved by elemental analysis, IR spectroscopy and method NMR, as well as determination of acid and ether numbers.

\section{Results and discussion}

Physico-chemical properties of esters are given in Table 1.

The viscosity-temperature and thermooxidative properties of the synthesized esters were also determined (Tables 2,3). The acid number is determined according to GOST 5895-79, thermo- oxidative stability (TOS) according to GOST $23797-79$, volatility according to GOST 20354-74.

As can be seen from Table 2, the symmetric, asymmetric, and complex esters of TMCP in comparison with analogous esters of TMCH have low viscosity levels at $100 \mathrm{C}$ and $40^{\circ} \mathrm{C}$, low pour points, high flash points and viscosity index.

The results determining the thermooxidative stability of the esters also showed that, according to all indicators, the TMCP esters have relatively better indicators than the TMCH esters: acid number $1.30 \div 2.91 \mathrm{mg}$ $\mathrm{KOH} / \mathrm{g}$ versus $1.15 \div 3.18$, the precipitate is insoluble in isooctane $0.002 \div 0.141 \%$ of the mass versus $0.004 \div 0.180$, volatility of $0.010 \div 0.50 \%$ of the mass against $0.65-0.69 \%$ of the mass.

The synthesized esters of cyclic polyatomic alcohols were investigated as antioxidant additives wich improve the TOS of diesel fuels. By adding to diesel fuels in an amount of 0.10.004 mass \% of these ethers, a number of compositions were prepared and settled on the optimal option -0.004 mass \%. Studied all the indicators of the compositions of diesel fuels, the results of which are given in Table 4.

The TOS of the prepared samples was determined in an LSART apparatus at $150^{\circ} \mathrm{C}$ for 4 hours (GOST 9144-79), flash point in a closed crucible in the TVZ-LAB-11 apparatus according to GOST 6350, ASTDM 93/SD 2719. 
Table 1. Physico-chemical properties of synthesized esters

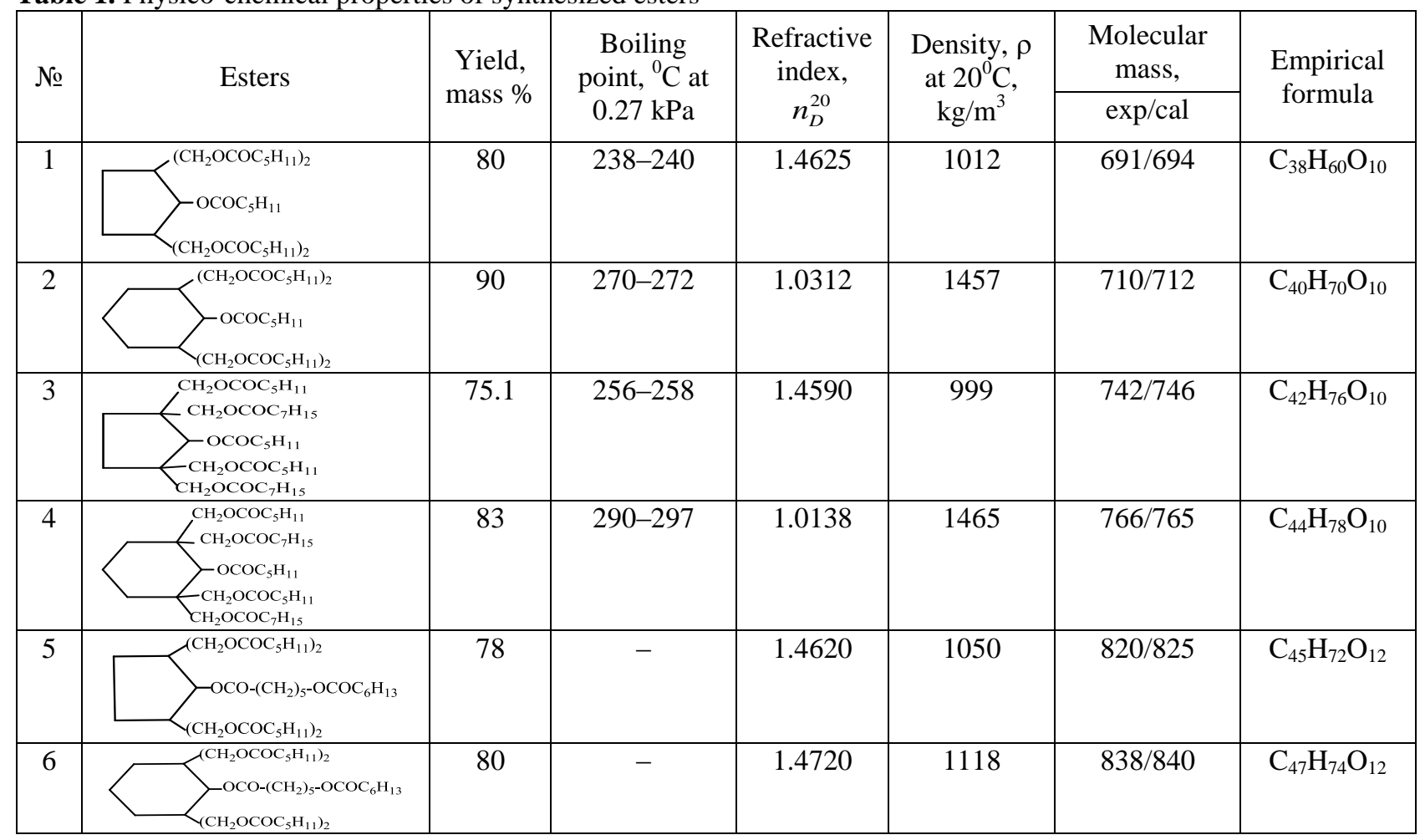

Table 2. The viscosity-temperature properties of the synthesized esters

\begin{tabular}{|c|c|c|c|c|c|c|}
\hline \multirow{2}{*}{$\begin{array}{c}\text { Number of } \\
\text { esters }\end{array}$} & \multicolumn{3}{|c|}{ Viscosity, $\mathrm{mm}^{2} / \mathrm{s}$, at temper. ${ }^{0} \mathrm{C}$} & \multirow{2}{*}{$\begin{array}{l}\text { Viscosity } \\
\text { index }\end{array}$} & \multicolumn{2}{|c|}{ Temperature, ${ }^{0} \mathrm{C}$} \\
\hline & 100 & 40 & -30 & & flash point & pour point \\
\hline 1 & 7.90 & 34.20 & 26346 & 126 & 290 & -53 \\
\hline 2 & 10.28 & 42.23 & 26500 & 125 & 281 & -47 \\
\hline 3 & 8.61 & 36.28 & 26760 & 138 & 309 & -50 \\
\hline 4 & 10.47 & 44.51 & 24300 & 135 & 291 & -44 \\
\hline 5 & 17.90 & 56.23 & - & 136 & 320 & -37 \\
\hline 6 & 17.98 & 71.63 & - & 125 & 334 & -31 \\
\hline
\end{tabular}

Table 3. Thermo- oxidative stability of esters of TMCP and TMCH

\begin{tabular}{|c|c|c|c|c|c|c|}
\hline \multirow{2}{*}{$\begin{array}{l}\text { Number } \\
\text { of esters }\end{array}$} & \multirow{2}{*}{$\begin{array}{c}\text { Viscosity at } \\
100^{\circ} \mathrm{C}, \mathrm{mm}^{2} / \mathrm{s} \\
\text { (after oxidation) }\end{array}$} & \multirow{2}{*}{$\begin{array}{c}\text { Acid number, } \\
\text { mg } \mathrm{KOH} / \mathrm{g} \\
\text { (after oxidation) }\end{array}$} & \multirow{2}{*}{$\begin{array}{c}\text { Precipitate insolu- } \\
\text { ble in isooctane, } \\
\text { mass } \%\end{array}$} & \multicolumn{2}{|c|}{ Corrosion, $\mathrm{mg} / \mathrm{cm}^{2}$} & \multirow{2}{*}{$\begin{array}{c}\text { Volatility, } \\
\text { mass. } \%\end{array}$} \\
\hline & & & & AK-4 & ШХ-15 & \\
\hline 1 & 8.82 & 1.30 & 0.002 & 0.120 & 0.025 & 0.010 \\
\hline 2 & 11.40 & 1.15 & 0.004 & 0.015 & 0.018 & 0.65 \\
\hline 3 & 9.60 & 1.40 & 0.003 & 0.130 & 0.030 & 0.018 \\
\hline 4 & 11.56 & 1.36 & 0.010 & 0.022 & 0.035 & 0.50 \\
\hline 5 & 19.23 & 2.91 & 0.141 & 0.110 & 0.133 & 0.50 \\
\hline 6 & 19.80 & 3.18 & 0.180 & 0.100 & 0.130 & 0.69 \\
\hline
\end{tabular}


Table 4. Test results for diesel fuel with the addition of esters

\begin{tabular}{|c|c|c|c|c|c|c|c|}
\hline \multirow[t]{2}{*}{ Indicators } & \multirow[b]{2}{*}{ DF } & \multicolumn{6}{|c|}{ Samples of diesel fuels with ethers } \\
\hline & & I & II & III & IV & $\mathrm{V}$ & VI \\
\hline $\begin{array}{l}\text { Density at } 20^{\circ} \mathrm{C}, \mathrm{kg} / \mathrm{m}^{3} \\
\text { at } 15^{\circ} \mathrm{C} \\
\text { at } 20^{\circ} \mathrm{C}\end{array}$ & $\begin{array}{l}845.8 \\
844.6\end{array}$ & $\begin{array}{l}846.5 \\
846.0\end{array}$ & $\begin{array}{l}846.5 \\
846.2\end{array}$ & $\begin{array}{l}847.2 \\
845.4\end{array}$ & $\begin{array}{l}847.6 \\
847.2\end{array}$ & $\begin{array}{l}845.9 \\
844.3\end{array}$ & $\begin{array}{l}846.1 \\
844.6 \\
\end{array}$ \\
\hline $\begin{array}{l}\text { Kinematic viscosity at } 20^{0} \mathrm{C} \text {, } \\
\mathrm{mm}^{2} / \mathrm{s}\end{array}$ & 6.80 & 6.20 & 5.90 & 5.75 & 5.80 & 5.83 & 5.92 \\
\hline Pour point, ${ }^{0} \mathrm{C}$ & -18.2 & -24.3 & -22.6 & -25.1 & -21.8 & -23.7 & -22.4 \\
\hline Aromathydrocarbon content, $\%$ & 17.6 & 17.3 & 17.1 & 17.8 & 18.0 & 18.2 & 17.9 \\
\hline Acidity, mg KOH/100 ml of fuel & 0.0026 & 0.0026 & 0.0029 & 0.0030 & 0.0034 & 0.0030 & 0.0035 \\
\hline $\begin{array}{l}\text { Thermo-oxidative stability, mg } \\
\text { sediment } 100 \mathrm{ml} \text { of fuel, (with } \\
\text { esters in the fuel } 0.004 \% \text { ) }\end{array}$ & 8.6 & 0.6 & 1.9 & 2.2 & 3.0 & 3.2 & 3.6 \\
\hline $\begin{array}{l}\text { Test on a copper plate, } 3 \text { hours at } \\
50^{\circ} \mathrm{C}\end{array}$ & $\mathrm{r}$ & $\mathrm{e}$ & $\mathrm{s}$ & $\mathrm{i}$ & $\mathrm{s}$ & $\mathrm{t}$ & $\mathrm{s}$ \\
\hline Coking ability of $10 \%$ residue, $\%$ & 0.0025 & 0.0020 & 0.0023 & 0.0021 & 0.0023 & 0.0020 & 0.0025 \\
\hline In closed cup flash point, ${ }^{0} \mathrm{C}$ & 76 & 84 & 80 & 86 & 82 & 88 & 83 \\
\hline $\begin{array}{l}\text { Fractional composition, }{ }^{0} \mathrm{C} \\
\text { İnitial boiling point }\end{array}$ & 206 & 202 & 204 & 200 & 203 & 210 & 213 \\
\hline $50 \%$ distilled at temperature & 275 & 275 & 270 & 277 & 272 & 280 & 281 \\
\hline $96 \%$ distilled at temperature & 350 & 352 & 354 & 352 & 356 & 360 & 362 \\
\hline End-boiling point & 354 & 356 & 358 & 354 & 360 & 362 & 370 \\
\hline Mass fraction of sulfur, ppm & 330 & 328 & 332 & 330 & 334 & 326 & 329 \\
\hline Cetane number & 45 & 44.6 & 44.2 & 44.8 & 44.0 & 44.5 & 44.1 \\
\hline
\end{tabular}

As a result of studies, it was found that the addition of ethers almost does not affect the fractional composition of diesel fuels, $96 \%$ are distilled in the range $350-362^{\circ} \mathrm{C}$, the density of all samples is $845-847 \mathrm{~kg} / \mathrm{m}^{3}$.

The addition of esters of TMCP and TMCH leads to an increase in the TOS of all samples of the tested fuels, what is determined by the amount of precipitate formed. As can be seen from Table 4, on adding $0.004 \%$ of esters of various structures to diesel fuel in six samples, it decreases from 8.6 to $0.6-3.6 \mathrm{mg} / 100$ $\mathrm{ml}$. The coke ability of the $10 \%$ residue also decreases: from 0.0025 to $0.0020 \%$. The flash point in a closed cup raises from 76 to $88^{\circ} \mathrm{C}$, the pour point decreases from minus $18.2^{0} \mathrm{C}$ to minus $25.1^{\circ} \mathrm{C}$. Among the given esters, the best indicators are symmetric and asymmetric esters of TMCP, which is directly related to the conformational state of the cyclopentane ring [7]. In comparison with complex esters (esters 5, 6), symmetric and asymmetric esters of these alcohols have a certain advantage, which are explained by the fact that they have simple molecular structures and, during oxidation, form labile and stable peroxide compounds with different thermal stability and initiating ability.

There is scientific information [8] that the effect of esters on the quality of fuels occurs according to a radical mechanism. It is also suggested that two types of peroxide compoundslabile and stable, with different thermal stability and initiating ability are formed under ester oxidation conditions [9]. Labile peroxide compounds represent $\alpha$ - and $\beta$-acyloxyhydroperoxides and their products inside molecular isomerization. They decompose with high speeds without the formation of free radicals.

Comparison of esters of cyclic polyatomic alcohols - TMCP and TMCH with known antioxidant additives based on screened phenols (ionol) shows that these esters have significant advantages $[2,3]$. In the case of adding $0.04 \%$ ionol, the precipitate makes up $1-1.5 \mathrm{mg} / 100 \mathrm{ml}$ of fuel.

\section{Conclusions}

Relying on the results of the work performed, it was found that the addition of esters of cyclic polyatomic alcohols of various structures leads to significant increases in TOS, flash point, as well as lowering the pour point of diesel fuels. 
Symmetric, asymmetric and complex esters of cyclic polyatomic alcohols - TMCP and TMCH can be recommended as complex additives to diesel fuels [10-11].

\section{References}

1. Pat. 2042709 RF. Additive to fuel. Gershanov F.B., Voronina O.A., Klinaeva E.V., Lyubimov N.V., Golubeva I.A. 1995.

2. Pat. 2372382 RF. Additive to increase the thermal-oxidative stability of hydrocarbon jet fuel and jet fuel. Varlamova N.I., Fedorov E.P., Vishnyakova T.P., Yanovsky L.S., Golubeva I.A., Pustyrev O.G. 2009.

3. Moikin A.A. Prospects for the development of the production of additives to oils, diesel fuels. The world of petroleum products. 2006. № 1. P. 24-27.

4. Mamedyarov M.A., Gurbanov G.N., Yusifova L.M. Alkyl-substituted esters of cyclic polyols as a base and component of lubricating oils. The world of petroleum products. 2019. № 5. P. 27-31.

5. Mamedyarov M.A., Gurbanov G.N., Yusifova L.M. Synthesis and study of esters of 2,2,5,5tetramethylolcyclopentanol as a base and compo- nent of lubricating oils. Oil and gas technology. 2019. №3.P. 22-26.

6. Mamedyarov M.A., Gurbanov G.N., Yusifova L.M. Synthesis of complex oligoesters of cyclic polyols and investigation of them as high temperature lubricating oils. Proceedings of the Azerbaijan National Academy of Sciences. 2019. No 1. P. 48-52.

7. Iliel E. Fundamentals of stereochemistry. M.: BINOL. Laboratory of knowledge, 2014. $120 \mathrm{p}$.

8. Emanuel N.M., Zaikov G.E., Maisus Z.K. The role of the medium in radical chain reactions of oxidation of organic compounds. M.: Nauka, 1973. $279 \mathrm{p}$.

9. Denisov E.T., Kovalev G.I. Oxidation and stabilization of jet fuels. M.: Chemistry, 1983. $272 \mathrm{p}$.

10. Mitusova T.N., Polina E.V., Kalinina M.V. Modern diesel fuels and additives to them. M.: Tekhnika, 2002. $64 \mathrm{p}$.

11. Mitusova T.N., Khavkin V.A., Gulyaev L.A., Kalinina M.V., Vinogradov N.Ya. The current state of production of low-curing diesel fuels in Russian plants. The world of petroleum products. 2012. No 2. P. 6-8.

\section{TSIKLIK ÇOXATOMLU SPIRTLORİN EFİRLəRİ İLə DİZEL YANACAQLARININ TERMOOKSIDLOŞMӘ XASSЭLəRININ YAXŞILAŞDIRILMASI}

\section{L.M.Yusifova}

2,2,5,5-tetrametiloltsiklopentanol və 2,2,6,6-tetrametiloltsikloheksanolun bir sira simmetrik, qeyri-simmetrik va kompleks efirləri sintez olunmuş, onların fiziki-kimyəvi, özlülük-temperatur və termooksidləşmə xassələri öyrənilmişdir. Bu efirlərin $0.004 \%$ miqdarında hidrotəmizlənmiş dizel yanacağına əlavə edilməsi ilə yanacaqların istismar xassələri xeyli yaxşılaşmışdır: termooksidləşmə stabilliyi, alışma temperaturu artır və donma temperaturu isə aşağı düşür. Bu nəticələrə əsasən, tsiklik çoxatomlu spirtlərin efirləri dizel yanacağına kompleks əlavələr kimi tövsiyə olunur.

Açar sözlar: tsiklik poliolların efirlari, sürtkü yağları, dizel yanacă̆l, istismar xassalari, kompleks alavalar

\section{УЛУЧШЕНИЕ ТЕРМООКИСЛИТЕЛЬНОЙ ХАРАКТЕРИСТИКИ ДИЗЕЛЬНЫХ ТОПЛИВ ЭФИРАМИ ЦИКЛИЧЕСКИХ МНОГОАТОМНЫХ СПИРТОВ}

\section{Л.М.Юсифова}

Синтезирован ряд симметричных, несимметричных и комплексных эфиров 2,2,5,5-тетраметилолциклопентанола и 2,2,6,6-тетраметилолциклогексанола, изучены их физико-химические, вязкостно-температурные и термоокислительные свойства. С добавлением этих эфиров к гидроочищенным дизельным топливам $0,004 \%$ удалось значительно улучшить эксплуатационные свойства топлив: повысить термоокислительную стабильность, температуру вспышки и снизить температуру застывания. Исходя из этих результатов эфиры циклических многоатомных спиртов рекомендованы в качестве комплексных добавок к дизельным топливам.

Ключевые слова: эфиры циклических полиолов, смазочные масла, дизельное топливо, эксплуатационные характеристики, комплексные добавки. 